\title{
The Impact of Supramolecular Complex of Glycyrrhizic Acid with Phytohormones on the Wheat (Triticum aestivum L.) Productivity
}

\author{
Djuraev A. Tulkin* and Khabibjon Kh. Kushiev
}

Ministry of Higher and Secondary Special Education of the Republic of Uzbekistan, Gulistan State University, 120100, Gulistan city, Republic of Uzbekistan

*Corresponding author

\section{A B S T R A C T}

\begin{tabular}{|l|}
\hline K e y w o r d s \\
Glycyrrhizic acid, \\
Phytogormones, \\
Supramolecular \\
complexes, Wheat, \\
Productivity
\end{tabular}

Keywords

Glycyrrhizic acid, complexes, Wheat,

\section{Introduction}

Meeting the food needs of the population is of strategic importance. Accordingly, increasing the yield and quality of crops is one of the important issues before science. The main purpose of finding a solution to the existing problem in this direction is to identify new physiologically active substances that contribute to the growth and development in connection with increasing the yield of the plant and have a biostimulatory property. This is also reflected in a number of works (Shakirova, 2001; Shabala et al., 2009; Shishkanu and Titova, 2008).
In Uzbekistan, wheat (Triticum aestivum L.) is one of the main types of crops grown in ancient times (Baboev et al., 2016).

The creation and increase of the yield of wheat varieties adapted to local soil and climatic conditions, resistant to pathogens and pests, in the country's agriculture is also relevant today. In this regard, it is important to theoretically/practically study the characteristics of changes in the dynamics of morphometric indicators of plant growth and development under the influence of bioregulators. Since under the influence of external stress factors the intensity of the 
process of growth and development of crops and, in turn, the prospects of using phytohormones in increasing yields are highly estimated (Nemchenko, 1993; Derecha et al., 2001; Antonova, 2004; Djuraev et al., 2018; Qo'shiev, 2011).

The study also suggests that many endogenous bioregulators, with the exception of phytohormones, may participate in the regulation of physiological/biochemical processes at the cellular level, which form the basis of plant growth and development (Deeva and Sheleg, 1985).

It is noted that one of the promising agents is glycyrrhizic acid (GC) (Qo'shiev, 2011; Dushkin et al., 2016; Djuraev et al., 2018).

Mainly distinguish between plant hormones and slows phenolic compounds, inhibitors of absorption of acid and of ethylene, such as oksin, cytokinin, gibberellin, which stimulates the growth and development of plants (Galston and Kaur-Sawhney, 1999).

In addition, a number of organic substances with more hormonal properties have been identified, which also affect the growth and development of plants in very small concentrations, creating certain changes.

In some studies, it is noted that salicylic acid is a phytohormone, and it is recognized as an antagonist of phytohormones. Salicylic and jasmine acids are involved in plant protection against microbial damage (Kefeli et al., 1900).

The aim of the research is to study the impact of glycyrrhizic acid (GA) and some phytohormones - indole acetic acid (IAA); indole butyric acid (IBA); naphthalene acetic acid (NAA) and supramolecular complex of kinetin on the productivity indicator of wheat variety "Krasnodar-99" (Triticum aestivum L.).

\section{Materials and Methods}

Soil and climatic conditions of the site where the study was conducted

In the Syrdarya region (total land area $\sim 427$ 600 hectar), the acreage used in agriculture is 250 900 hectar, mainly types of irrigated land-meadow, flax-meadow, meadow-ice soil. Mechanical composition of soil $-1.9 \%$ clay; $11.7 \%$ heavy sand; $49.6 \%$ medium sand; $30 \%$ light sand; $6.2 \%$ sand and $0.6 \%$ sand character, in agriculture $12.4 \%$ of land is not salty (washed); $41.2 \%$ salty; $39.2 \%$ on average salty; $5.3 \%$ of highly saline and $1.9 \%$ of very saline soils, groundwater table is on average $\sim 1-5 \mathrm{~m}$; the degree of mineralization is $3-19$ $\mathrm{g} / 1$.

On the land plots where the studies were conducted, the soil mainly consists of slightly salted, hungry ice soils, the humus content in them is $0.5-1 \%$; mechanical compositionlight/moderately auxiliary soils and groundwater are located at a depth of 1-3 m.

\section{Objects of research}

Auxins are important in the process of plant growth and development (Galston and KaurSawhney, 1999), it was noted that the plant is also involved in the regulation of expression of genes encoding the biosynthesis of other phytohormones (Aloni, 2004).

Therefore, the main objects in the studies were selected phytohormones auxin (IAA, IBA, NAA) and kinetin.

The analysis of biological activity of supramolecular complexes of GA:phytohormone in wheat (Triticum aestivum L.) "Krasnodar-99" variety is used.

As it is known, wheat (Triticum aestivum L.) is a significant agricultural crop, animal feed, 
animal feed are used on an industrial scale as a valuable raw material and make up 20-30\% of crops grown worldwide (Neelambari et al., 2018).

Botanical description of wheat, systematic/morphophysiological

characteristics of wheat are described in detail in the studies of researchers (Genkel, 1969; Vavilov, 1986; Vasin et al., 2009).

Some varieties of soft wheat imported from Krasnodar region (Russia) and adapted to local soil and climatic conditions are characterized by an increased level of resistance to stress factors on the irrigated acreage of the Republic and high yields. One of the varieties of wheat, adapted to the conditions of the Syrdarya region and widely grown in agriculture, is an average grade "Krasnodar-99" (Lukyanenko P.P. created in Krasnodar Research Institute of agriculture), resistant to salting, the height of the vegetable ball is on average $\sim 900-950 \mathrm{~mm}$; without rosehip, cylindrical shape $(8-9 \mathrm{~cm})$; with a reddish tinge of grains, weighing about 1,000 pieces $~ 40-41 \mathrm{~g}$; in Syrdarya conditions, the average yield is $\sim 60-65$ centner/hectar; in the spring after the winter lunch temperature is $+5.8 \ldots$ at a temperature of $+6^{\circ} \mathrm{C}$, the vegetation period is restored, usually depending on the optimal range of planting time (15.09-25.10), the planting rate relative to the unit area is $\sim 4.8-6$ million pieces/hectares (Siddiqov, 2011).

Extraction of GA from root licorice (Glycirrhiza glabra L.) and chemical identification/synthesis of GA: phytohormone of supramolecular complexes

Local licorice in experiments (Glycirrhiza glabra L.) preparation of plant root extract and GA extraction from its composition, chemical identification, synthesis of GA:phytohormone supramolecular complexes based on standard methods (Kondratenko et al., 2001; Astafeva et al., 2013; Shlotgauer, 2013).

The impact of supramolecular complex of GA: phytohormones on the wheat (Triticum aestivum L.) productivity

The experiments were carried out in the standard style (Korxova, 2015), based on the organization of 1 control and 4 test sites (total $250 \mathrm{~m}^{2}$ ), the surface area of each of which is $25 \mathrm{~m}^{2}$ in the field (Fig. 1).

From each site in the control and experimental groups on the basis of random variation samples at the end of the growing season were selected 100 pieces of wheat balls, and in the laboratory counted the number of heads in vegetable balls (pieces), head length ( $\mathrm{mm})$, the number of grains in the head (pieces) and the weight of grain 1000 pieces $(\mathrm{g})$. On the basis of the obtained values, the value of the indicator of biological productivity of wheat was determined (Korxova, 2015).

It is known that the biological productivity of wheat is the amount of grain formed on the basis of biosynthesis of organic substances during photosynthesis and absorption of water/nutrients from the soil during the life of the plant organism in relation to the unit field (centner/hectares). The main components of the indicator of wheat yield are the density of crops in relation to the unit area; it consists of the weight of grain in 1 head (Volkov, 1999.) and is calculated using the following form (1) (Lixochvor, 2008):

$P_{\text {biol. }}=N P P \times T W G \times 10000 / 100000(1)$

$P_{b i o l}$ - biological productivity; NPP - location in relation to the unit area number of productive plants (pieces/m2); TWG - total weight of grain in 1 head $(\mathrm{g}) ; 10000$ conversion factor area of $1 \mathrm{~m}^{2}$ per 1 hectare (ha); 100 000-conversion factor value of $\mathrm{g} / \mathrm{ha}$ per centner/hectares. 
Sowing in the experimental plots was carried out 18.09.2019 years, normal $\sim 5000 \quad 000$ pcs/hectares. during the growing season were provided with water and mineral feed according to the established norms (including phase propagation $\sim 100 \mathrm{~kg} / \mathrm{ha}$; in the phase of collecting $\sim 200 \mathrm{~kg} / \mathrm{ha}$; in the phase of spraying $\sim 200 \mathrm{~kg} / \mathrm{ha}$ and in the phase of spraying $\sim 100$ $\mathrm{kg} / \mathrm{ha}$ ). It was noted that wintering occurs in the phase of formation of $\sim 2-3$ leaves on the plant (spraying).

There is a significant influence of sowing time, agrotechnical measures on the growth and development of wheat, the formation of productivity indicators (Korxova, 2015).

The table below shows the timing of sowing, vegetation/ontogenesis phase of the experimental plot of the wheat variety "Krasnodar-99" (Table 1).

In general, the growing season of wheat depends on the biological characteristics of varieties, soil and climatic conditions ( $85-$ 115 days) (Antonova, 2004).

In turn, it is noted that the formation of indicators of wheat yield is important environmental conditions (meteorological factors), agricultural activities (technological factors) (Volkov, 1999.).

Favorable from the meteorological point of view, the vegetation period determines the intensity of the phases of pipe formation and the formation of rosehip in the vegetable ball (Antonova, 2004).

\section{Data analysis}

Experimental results using standard biometric methods (Dospexov, 2014), OriginPro V. 8.5 SR1 (EULA, USA) mathematical statistics has been reworked using a special software package. The results are presented in the form of $M \pm m$ results of experiments carried out in repetition $\mathrm{n}$ times, and $\mathrm{M}$ is the arithmetic mean and $\mathrm{m}$ is the standard error value. Here, $\bar{x}_{\text {avg. is the ratio of the total sum of elements }}$ in the statistical selection to its volume, calculated using the following formula ( $\sum x$ ) as the ratio of the total sum (n) of the values obtained in the experiments to the number of experiments (2):

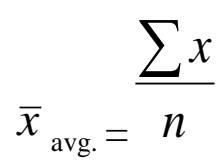

The deviation of the mean square edge $(\sigma)-$ the dispersion value expressed as the square root is calculated using the following formula (3):

$\sigma=\sqrt{\frac{\sum\left(x-\bar{x}_{y p m .}\right)^{2}}{n}}$ or $\sigma=\sqrt{\sigma^{2}}$

In addition, the results of the experiment were calculated on the basis of the Student T-test of the level of statistical reliability of the values between the variants and were evaluated as statistically significant in the values of $r<0.05$, $r<0.01$. The degree of reliability of differentiation between control and experimental values was calculated by The $t-$ Student criterion using the following formula (4):

$t=\frac{\bar{x}_{1}-\bar{x}_{2}}{\sqrt{m_{1}^{2}+m_{2}^{2}}}$

\section{Results and Discussion}

In experiments conducted in the field, cereals were used, including wheat (Triticum aestivum L.) yield is a standard method that provides sufficient adequate information on the assessment based on indicators of the 
number of heads in plant balls, the number of grains in ears and the weight of 1,000 pieces of grain in relation to the unit area (Kostylev et al., 2017).

In table 2 below shows the effect of supramolecular complexes of GA: phytohormones (IAA, NAA, IBA and kinetin) on the components of the indicator of the yield of wheat varieties "Krasnodar-99" in the field on the areas where the study was conducted (Fig. 2; Table 2).

It was noted that the yield of wheat is calculated depending on the density of plants forming in a unit of the field to $\sim 50 \%$ (Korxova, 2015).

In the experiments at the control site at the end of the growing season, the number of productive balls of the wheat variety "Krasnodar-99" is $-463.8 \pm 6.8$ grains, grain processing before planting at a concentration of $100 \mu \mathrm{mol} \cdot \mathrm{L}^{-1}$, as well as sowing in the upper plant organs in the spraying phase during the growing season are: IAA (4:1), GA:NA (4:1), GA:IBA (5:1) and GA:Kinetin in the conditions of treatment with, respectively, the value of this analyzed indicator- $476.3 \pm 4.6 ; 471.3 \pm 4.9 ; 468.4 \pm 5.3$ and it was found that $478.4 \pm 4.5$ pieces (Fig. 3A).

It is also noted that the yield of grain balls forming a spike in a field unit significantly affects the yield, and not the number of rosehips, mainly in the headdress (Korxova, 2015).

Both indicators noted by the authors of the above studies were found in experiments on the control of GA:supramolecular complexes of phytohormones.

According to the table 2 on the basis of the calculation of the yield of wheat cultivar
"Krasnodar-99" on the plot control is $58.5 \pm 2.6 \mathrm{with} / \mathrm{ha}(100 \%)$, processing of grain before planting at a concentration of 100 $\mu \mathrm{mol} \cdot \mathrm{L}^{-1}$, and the planting of plants in the phase of spraying in vegetation period GA:IAA (4:1), ha:NAA (4:1), ha:IBA (5:1) and GA:Kinetin in terms of the processing of, respectively, relative to the control rate of $51.9 \%$ (88.9 \pm 3.7 centner/hectares); and $35.4 \%$ (79.2 \pm 3.4 centner/hectare); 7.9 percent (to $63.1 \pm 4.5$ centner/hectares) and $43.9 \%$ (84.2 \pm 5.8 centner/hectares) (Fig. 3B).

Many researchers noted that bioregulators are promising agents in increasing wheat yield in modern agricultural conditions (Shakirova, 2001; Shishkanu and Titova, 2008; Shabala et al., 2009; Djuraev and Kushiev, 2018).

It was noted that the effectiveness of the use of phytoregulators in seed treatment before planting in order to increase resistance to stress factors during the growing season of crops, optimize growth and development (Djuraev and Kushiev, 2018).

Thus, the indicators of plant productivity are determined by the value of morphometric/ physiological parameters of plant organs that determine the formation and quantity of the crop (density of the productive plant ball; the number of ears and the number of grains in the head) and are formed under the influence of a complex of environmental conditions that determine the genotype/phenotype (Korxova, 2015).

In particular, indicators of autumn wheat yield indicate abiotic/meteorological conditions (temperature, humidity, etc.) and biotic (pathogens, etc.) factors (Korxova, 2015) are formed under the influence of agrotechnical measures of the growing season (Antonova, 2004). 
Table.1 Terms of phases of ontogenesis during the growing season in the experimental areas of the variety "Krasnodar-99"

\begin{tabular}{|c|c|c|c|c|}
\hline Planting & Brairding & Forming ovary & Spiking & Ripenning \\
\hline 18.09 .2018 & 06.10 .2018 & 04.04 .2019 & 04.05 .2019 & 14.06 .2019 \\
\hline
\end{tabular}

Table.2 Influence of supramolecular complexes GA: phytohormones (IAA, NAA, IBA and kinetin) on the components of the indicator of wheat yield of the "Krasnodar-99" variety $(M \pm m)$

\begin{tabular}{|c|c|c|c|c|c|c|}
\hline $\begin{array}{l}\text { Experimental } \\
\text { varaints }\end{array}$ & $\begin{array}{l}\text { Height of a } \\
\text { plant }(\mathrm{mm})\end{array}$ & $\begin{array}{c}\text { Number of } \\
\text { productive } \\
\text { plants } \\
\left(\mathrm{pcs} / \mathrm{m}^{2}\right)\end{array}$ & $\begin{array}{c}\text { Number } \\
\text { of bushes } \\
\text { of plants } \\
\text { (pcs) }\end{array}$ & $\begin{array}{l}\text { Length of a } \\
\text { head }(\mathrm{mm})\end{array}$ & $\begin{array}{c}\text { Number } \\
\text { of grains } \\
\text { on heads } \\
\text { (pcs) }\end{array}$ & $\begin{array}{c}\text { Weight of } \\
1000 \text { pcs } \\
\text { of grains } \\
(\mathrm{g})\end{array}$ \\
\hline Con & 4 & $463,8 \pm 6,8$ & $3,4 \pm 1,2$ & & $32,5 \pm 3,8$ & $38,8 \pm 7,4$ \\
\hline $\begin{array}{l}\text { GA:IA } \\
100 \mu \mathrm{m}\end{array}$ & $960,3 \pm 3$ & $476,3 \pm 4,6 * *$ & $3,6 \pm 2,4 * *$ & $106,5 \pm$ & $43,6 \pm 6,3^{* *}$ & $42,8 \pm 6,7 * *$ \\
\hline $\begin{array}{r}\mathrm{GA}: \mathrm{N} \\
100 \mu\end{array}$ & 954 & 471 & $4,1=$ & 103 & 41 , & \\
\hline $\begin{array}{l}\text { GA:II } \\
100 \mu\end{array}$ & 946 & 468 & $3,8 \pm 2$ & 94 & $4 *$ & 39 \\
\hline $\begin{array}{c}\text { GA:Kinetin }(4: 1) \\
100 \mu \mathrm{mol} \cdot \mathrm{L}^{-1}\end{array}$ & $932,2 \pm 6,6^{* *}$ & $478,4 \pm 4,5 * *$ & $3,7 \pm 1,8 * *$ & $102,4 \pm 6,8 * *$ & $42,7 \pm 5,2 * *$ & $41,2 \pm 3,7 * *$ \\
\hline
\end{tabular}

Note: In the experiments GA:IAA (B), GA:NAA, in the ratio and GA:IBA 5:pre-planting grain treatment in the ratio $1\left(100100 \mu \mathrm{mol} \cdot \mathrm{L}^{-1}\right)$, as well as sowing plants in the pipeline phase during vegetation is used. * - the difference between the values of the experimental group in relation to the control statistical level of reliability $p<0,05, * *-p<0,01$.

Fig.1 Scheme of experiments to study the effect of GA:phytohormones (IAA, NAA, IBA and kinetin) on the yield of wheat varieties "Krasnodar-99" in the field of supramolecular complexes

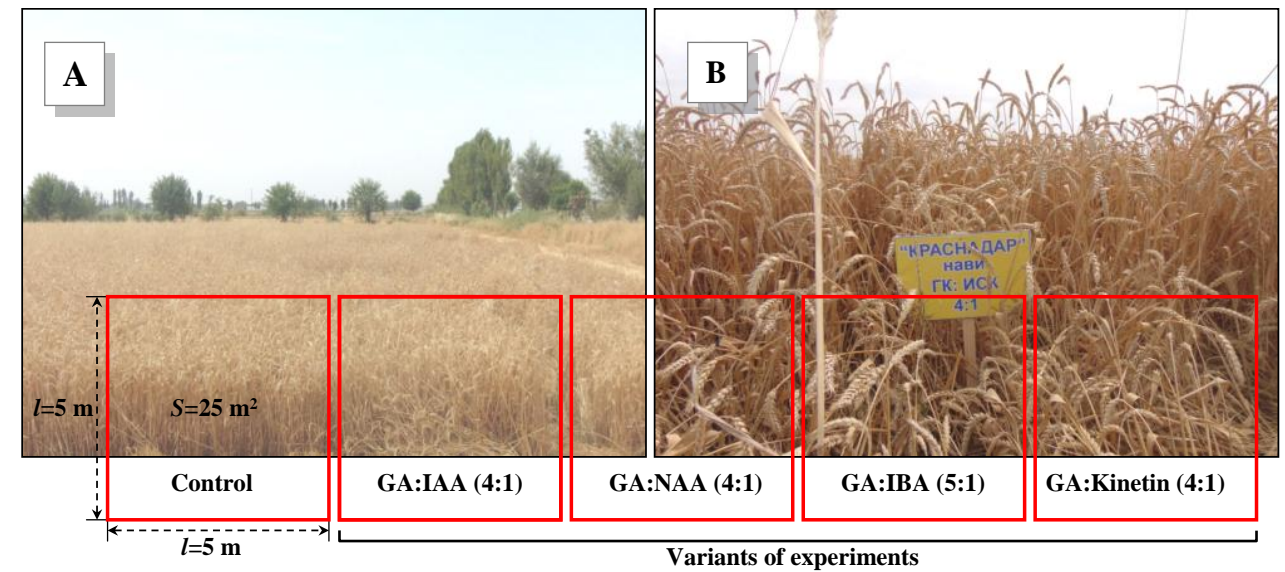

The experiments were conducted in 2019 (autumn-spring) at the experimental site of Gulistan State University (A), located on the territory of Gulistan district of Syrdarya region. GA:IAA (B), GA:NAA, GA:Kinetin was used in a 4:1 ratio and a pre-planting grain treatment method in a 5:1 $\left(100 \mu \mathrm{mol} \cdot \mathrm{L}^{-1}\right)$ ratio of GA: IBA, as well as in the spraying phase during the growing season, sprinkling the plant. 
Fig.2 A. Experimental site to study the effect of supramolecular complexes GA: phytohormones on the yield of wheat variety "Krasnodar-99". B. The Process of analysis of morphometric parameters of wheat in the laboratory (Gulistan State University, 25.06.2019)

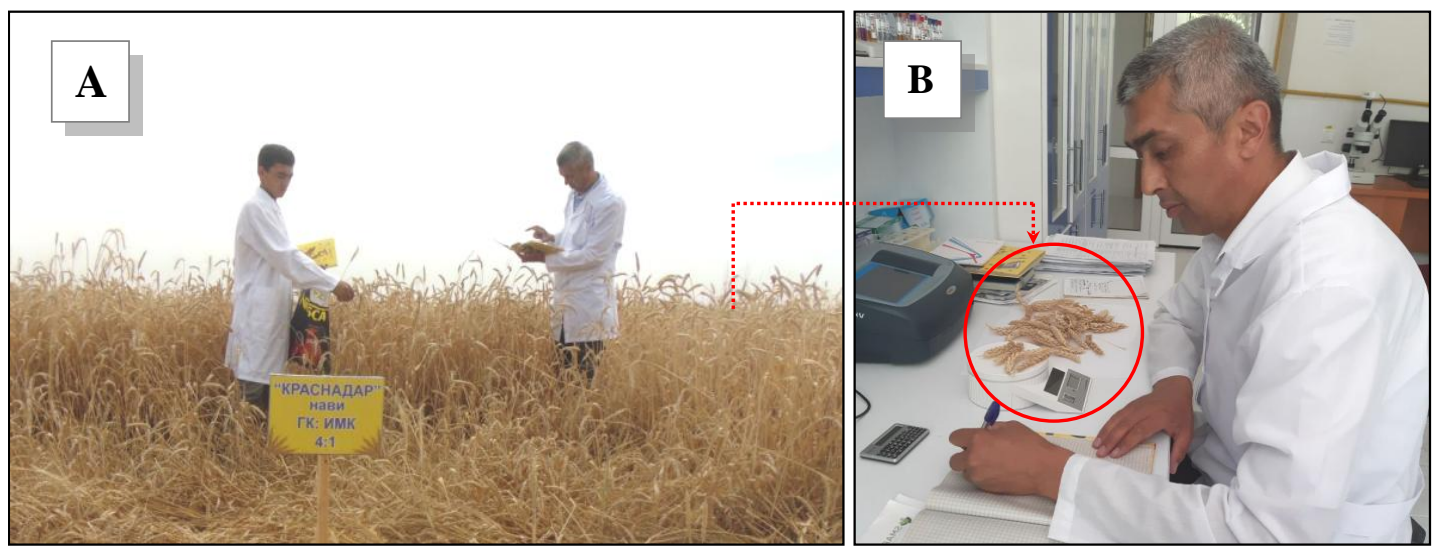

Fig.3 Influence of supramolecular complexes GA: phytohormones (IAA, NAA, IBA and kinetin) on the quantity of plants (pieces $/ \mathrm{m}^{2}$ ) (A) and yield (B) of wheat variety "Krasnodar-99"
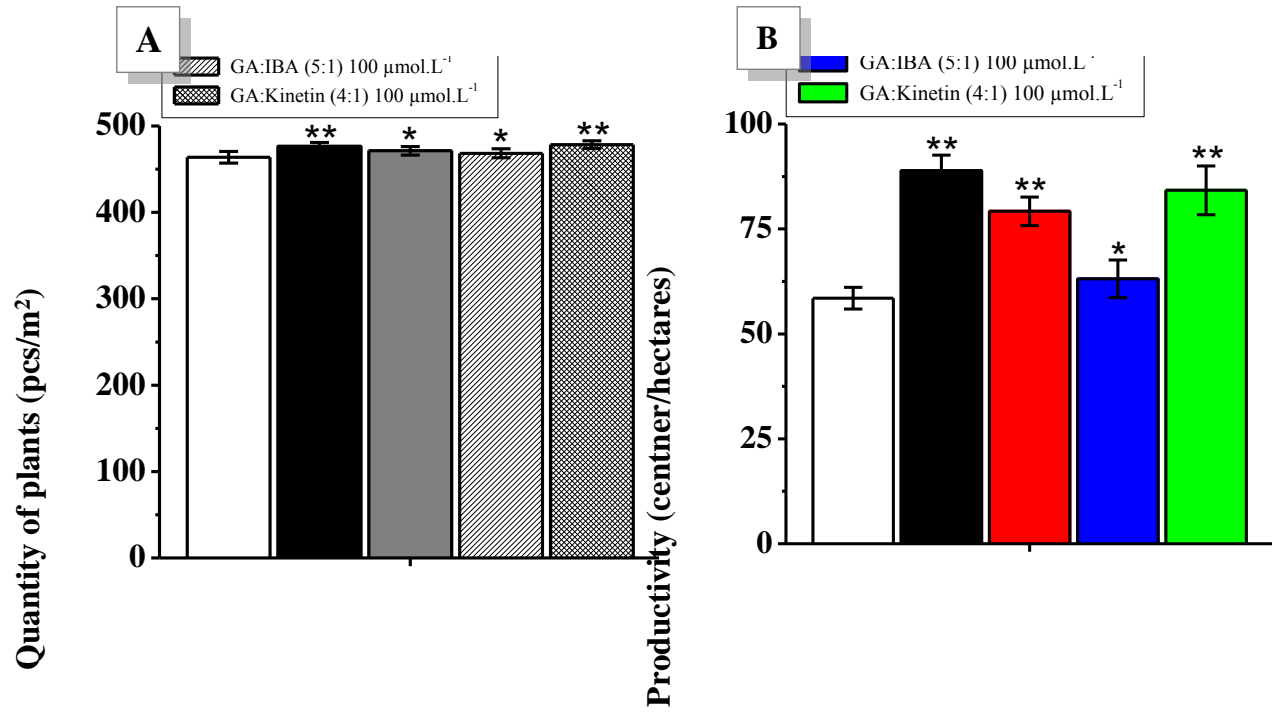

A. On the axis of the ordinate - the quantity of plants $\left(\mathrm{pcs} / \mathrm{m}^{2}\right)$; B. on the axis of the ordinate - expressed productivity (centner/hectare) $(*-p<0,05 ; * *-p<0,01)$.

At the same time, the soft wheat variety is relatively resistant to cold and the optimal yield is $+12 \ldots$ It is in the range of $+15^{\circ} \mathrm{C}$ and +4 in autumn.

Intensive development at a temperature of $+5^{\circ} \mathrm{C}$, but a sharp drop in temperature adversely affects (Vavilov, 1986).
According to the results of the experiment it was found that the density of the wheat variety "Krasnodar-99" in the field at the beginning of the growing season in the spring is much higher than the control mark:under the influence of supramolecular complexes of phytohormones (IAA, NAA, IBA and kinetin). This condition can be attributed to 
increased level of frost resistance of plants in winter under the influence of the GE:phytohormones complexes. The results obtained correspond to the available literature data. In particular, the study showed that biologically active substances increase resistance to wheat cold to exogenous phytohormones noted by some researchers (Antonova, 2004; Korxova, 2015).

In general, bioregulators (phytohormones, etc.) under the influence of various stress factors, there is an increase in the level of resistance to wheat and, in turn, an increase in yield (Shakirova, 2001; Shishkanu and Titova, 2008; Shabala et al., 2009). Under the influence of biologically active substances, especially under the influence of stressful factors, an increase in the intensity of the photosynthesis process is observed in the plant's body, under the influence of IA, kinetin, the total protein content in wheat grain, the amount of starch in cereals, the total weight of 1000 pieces of grain, a significant increase in yield in the final case (Shakirova, 2001; Shishkanu and Titova, 2008; Shabala et al., 2009).

In addition, some researchers found that phytohormones (aucsin, cytokinin, etc.) in combination with the yield of grain crops had a positive effect on grain quality indicators (Antonova, 2004).

Under the influence of phytohormones was found to increase the level of absorption of seeds in water, increasing the intensity of respiration, increasing the activity of amylolytic enzymes, increasing productivity in the laboratory and field conditions. It is noted that the treatment of seeds of grain crops with phytohormones before planting increases the degree of adaptation of the plant to adverse environmental conditions, in turn, has a positive effect on yield (Antonova, 2004).
Thus, seed treatment with phytohormones before planting has an increasing effect on yield, the absorption of plant nutrients activates the process, increases resistance to phytopathogens (Genkel, 1969), has a positive effect on the processes of seed cultivation, increases resistance to stress factors, increases productivity in the final state by increasing the intensity of the formation of yield elements (Korxova, 2015).

Thus, it is important to develop and implement technologies that optimize the formation of structural elements of wheat in agriculture.

Studies have shown that the effects of GAphytohormones, optimizing the wheat yield of supramolecular complexes, were implemented on the basis of a wide range of biochemical/physiological mechanisms, including - activation of enzymes of functional importance in the body of the plant, activation of metabolism due to the intensity of mechanisms of intracellular signal transduction, in turn, increasing the level of stability of the antioxidant/immune system.; various biotic/abiotic stress factors of the plant (cold, phytopathogens, etc.) to increase the degree of resistance to influence on the reproductive organs ultimately may be due to the stimulation of formation of the reproductive organs and elements of the performance indicator.

The obtained experimental results confirm the high prospect of further use of supermolecular complexes GA and phytohormones (IAA, NAA, IBA and kinetin) on the basis of economic resource saving in order to optimize crop yields in practice.

\section{References}

Aloni, R. 2004. The induction of vascular tissue by auxin. Plant hormones: 
biosintesis, signal transduction, action. (Ed. Davies P.J. Dordrecht et al.,). Kluwer Acad. Publ., Pp. 471-492.

Antonova, T.A. 2004; Formirovanie urojaya, zimostoykost i kachestvo zerna ozimoy rji pri ispolzovanii melafena $\mathrm{v}$ usloviyax lesostepi Povoljya. Avtoreferat diss.... k.selsk. - -x.n. Ulyanovsk: 3-21. (Russian).

Astafeva, O.V., Suxenko, L.T., yegorov, M.A. 2013. Protivomikrobnaya aktivnost vydelennyx biologicheski aktivnyx veщestv i ekstrakta kornya Glycyrrhiza glabra L. Ximiya rastitelnogo syrya. 3: 261-263. (Russian).

Baboev C., Morgunov A., Mumindjanov X. 2016. Staromestnye sorta pshenitsy na fermerskix polyax $\mathrm{v}$ Uzbekistane. Ankara (Prodovolstvennaya i selskoxozyaystvennaya organizatsiya OON): 1-5. (Russian).

Deeva, V.P., Sheleg, Z.I. 1985. Regulyatory rosta i urojay. Moskva. Izd-vo «Nauka i texnika»: 10-63. (Russian).

Derecha, A.A., Dajuk, M.A., Klyuchevich, M.M. 2001. Effektivnost regulyatorov rosta na ozimoy pshenitse $\mathrm{v}$ usloviyax polesya Ukrainy. Tez.dokl. «Regulyatory rosta i razvitiya rasteniy $\mathrm{v}$ biotexnologiyax». - Moskwa: 233. (Russian).

Djuraev, T., Kushiev, Kh. H., Gafurov, M.B. 2018. Stimulating properties of components glycyrrhizic acid in growth and development of wheat (Triticum aestivum). J. Biol. Chem. Research. 35(2): 323-310. (Russian).

Dospexov, B.A. 2014. Metodika polevogo opyta (s osnovami statisticheskoy obrabotki rezultatov issledovaniy). Moskva. Izd-vo «Agroproizdat»: 110 351. (Russian).

Dushkin, A.V., Meteleva, E.S., Xomichenko, N.N., Vlasenko, N.G., Teplyakova, O.I., Xalikov, M.S., Xalikov, S.S. 2016.
Novyy pestitsidnyy preparat na osnove kompleksov tebukonazola i proizvodnyx glitsirrizina. Uspexi sovremennogo yestestvoznaniya. 1112: 296-300. (Russian).

Galston, A.W., Kaur-Sawhney, R. 1999. Polyamines as endogenous growth regulators. In: Plant Hormones. Physiology, Biochemistry and Molecular Biology. (Ed. By PJ. Davies). Kluwer Acad. Publishers. Dordrecht-Boston-London: 221-240.

Genkel P.A. 1969. Fiziologiya selskoxozyaystvennyx rasteniy. T.4. Fiziologiya pshenitsy. Moskva. Izd-vo Mos. gos. un-ta.: 7-42. (Russian).

Kefeli, V.I., Vlasov, P.V., Prusakova, L.D. i dr. 1990. Prirodnye i sinteticheskie regulyatory rosta rasteniy. Itogi nauki i texniki. Fiziologiyarasteniy. T.7. 154169. (Russian).

Kondratenko, R.M., Baltina, L.A., Mustafina, S.R. et al., 2001. Method synthesis of crystalline glycyrrhizic acid from industrial Glycyrram. Immunomo dulating properties. Chem. Pharm. Journal. 35: 38-42.

Korxova, M.M. 2015. Formirovanie osnovnyx elementov produktivnosti sortov pshenitsy ozimoy $\mathrm{v}$ zavisimosti ot srokov seva $\mathrm{i}$ norm vyseva $\mathrm{v}$ usloviyax yujnoy stepi Ukrainy. Stiinta agricola. 1: 19-23. (Russian).

Kostylev, P.I., Krasnova, E.V., Donsova, V. Yu., Kostyleva, L.M. 2017. Vliyanie elementov struktury urojaya na produktivnost sortov risa kontrolnogo pitomnika. Mejdunarodnyy nauchnoissledovatelskiy jurnal. 07(61). Ch.2: 63-66. (Russian).

Lixochvor, V. 2008. Produktivnost i struktura urojaya ozimoy pshenitsy. URL: https://www.zernoua.com/journals/2008/iyul-2008$\mathrm{god} /$ produktivnost-i-strukturaurozhaya-ozimoy-pshenicy. (Russian). 
Neelambari, Mandavia Ch., Ganesh S.S. 2018. Curative effect of ascorbic acid and gibberellic acid on wheat (Triticum astivum L.) metabolism under salinity stress. Int. J. Curr. Microbiol. App. Sci. 7(1): 522-533.

Nemchenko, B.B. 1993. Ispolzovanie regulyatorov rosta dlya povysheniya ustoychivosti $\mathrm{k}$ neblgopriyatnym usloviyam proizrastaniya. Tez. dokl. 2y konf. «Regulyatory rosta i razvitiya rasteniy». Moskva: 259. (Russian).

Qo'shiev, H.H. 2011. Bug'doyning o'sish va rivojlanishida biotik va abiotik omillar ta'sirini fiziologik faol moddalar yordamida idora etish // B.f.d. ilmiy darajasini olish uchun yozilgan dissertatsiya (02.00.10-bioorganik kimyo). Guliston: 9-231. (Uzbek).

Shabala, S., Pang, J., Zhou, M., Shabala, L., Cuin, T.A., Nick, P., Wegner, L.H. 2009. Electrical signalling and cytokinins mediate effects of light and root cutting on ion uptake in intact plants. Plant, cell \& Environment. 32(2): 194-207.

Shakirova F.M. 2001. Nespetsificheskaya ustoychivost rasteniy $\mathrm{k}$ stressovym faktoram i yee regulyasiya. Ufa: Gilem. 160. (Russian).
Shishkanu G.V., Titova N.V. 2008. Steroidnye glikozidy kak regulyatory fotosinteza seyansev plodovyx rasteniy. Simpozionul stiintific International «Agricultura moderna - realizari si perspective» dedicat aniversarii a 75 ani ai UASM (Horticultura). Lucrari stiintifice, Chisinau, 20: 124. (Russian).

Shlotgauer, A.A. 2013. Issledovanie vzaimodeystviya atorvastatina $\mathrm{s}$ triterpenovym glikozidom glitsirrizinovoy kislotoy metodom YaMR relaksatsii $\mathrm{v}$ rastvorax. Fundamentalnye issledovaniya. 10-13: 553-556. (Russian).

Siddiqov, R.I. 2011. Sug'oriladigan yerlarda kuzgi bug'doy navlari va ularni yetishtirish texnologiyasi. Toshkent: 56. (Uzbek).

Vasin, V.G., Vasin, A.V., yelchaninova, N.N. 2009. Rastenievodstvo. Samara: 238266. (Russian).

Vavilov, P.P. 1986. Rastenievodstvo. Moskva. Izd-vo Agropromizdat: 327336. (Russian).

Volkov, S.A. 1999. Osobennosti formirovaniya urojaya zerna yarovoy tverdoy pshenitsy i yachmenya $\mathrm{v}$ zavisimosti ot agropriemov. Atoreferat diss.... k.sel.-Xoz.n.: 3-19. (Russian).

\section{How to cite this article:}

Djuraev A. Tulkin and Khabibjon Kh. Kushiev. 2019. The Impact of Supramolecular Complex of Glycyrrhizic Acid with Phytohormones on the Wheat (Triticum aestivum L.) Productivity. Int.J.Curr.Microbiol.App.Sci. 8(08): 138-147. doi: https://doi.org/10.20546/ijcmas.2019.808.017 